\title{
English for Occupational Purposes: Transference, Expectations and Failures
}

\author{
Mercedes Rico \\ English Philology Department, University of Extremadura, Spain \\ Paula Ferreira da Silva \\ Official School of Languages, Extremadura, Spain \\ Laura V. Fielden \\ English Philology Department, University of Extremadura, Spain
}

\begin{abstract}
People live in a competitive society, searching for technical and professional expertise throughout their lifetimes. With the expansion of ICT and distance learning ${ }^{1}$, educational approaches are no longer restricted to formal education; rather learners are urged to acquire new skills and to obtain official and professional recognition of these competences. The general framework of our proposal is the result of a project $^{2}$, aimed at designing, testing, and disseminating Online/Multimedia English for Occupational Purposes courses (EOP), to recognize linguistic competence in professional environments(commerce and tourism). Our twofold study aims: (1) to research the transference rate and the factors that make EOP courses a successful proposal, and; (2) to gain insights into the main expectations, outcomes and failures of such courses. To achieve these objectives, twelve national, non-formal teaching enterprises delivering the courses were contacted, and questionnaires and interviews were created. The results show satisfaction with the courses and point to the lack of linguistic policies and the consequent influence on professional achievements.
\end{abstract}

Index Terms —EOP courses, online/multimedia, level recognition, professional achievements

\section{INTRODUCTION}

The history of humankind has always been marked by events that alter the status quo enabling changes. Natural phenomena, wars or economic crisis give rise to movements in the existing paradigms which consequently affect all segments of society, changing habits and minds (World Economic Forum, 2014).

One of the most striking phenomena of the last decades of the $20^{\text {th }}$ Century, and still present today, has been the development and implementation of technology in all human areas. The presence of technology and the world economic crisis facilitated the appearance of new demands in the labor market, emphasizing the acquisition of new competences and the constant update of theoretical and practical knowledge ${ }^{3}$. Work has become something that can be looked for and offered on a global scale, making it necessary to master newer competences, such as the acquisition of foreign languages as a basic skill to get a job and be mobile in a globalized market (Castiglione D., \& Longman, C. 2008). However, language policy involves a great deal of regulations and norms, being one of the main concerns the recognition of linguistic autonomy (Patten, 2001).

The EU defends the acquisition of at least two foreign languages (Commission of the European Communities, 2003) and aims to provide citizens with tools to develop linguistic skills at three levels (individual, social and cultural) for a better cognitive development, intercultural awareness and understanding of identity and roots. So, language competences are part of the core of skills that every citizen needs for training, employment, cultural exchange and personal fulfillment; language learning is a lifelong activity (Commission of the European Communities, 2003, p 7). However, knowing languages and doing a job well are no guarantee of success. In economically troubled times, versatility, adaptation and updating skills are necessary to thrive in a society marked by constant change. In recognition of this, the Council of Lisbon (Lisbon, 2000) set the bases to create eEurope, with the objective of developing access to Internet and the creation of a research and innovation area. A prime consequence of those actions was the eLearning Programme (Council of Lisbon, 2002) from which the so-called concept of digital literacy emerged. These new educational settings have proved to be a cost-effective solution because educational training can be achieved through elearning platforms, omitting the necessity for workers to leave their jobs in order to master newer skills, a continuous

\footnotetext{
${ }^{1}$ UNESCO, 2002, 2009; Commission of the European Communities, 2002, 2007, 2008, 2014; CEDEFOP, 2006

${ }^{2}$ Technological Development, Transfer and Innovation project funded by the Regional Government of Extremadura (Spain)

${ }^{3}$ European Commission, 2009 COM (2010) 682/3. Global Agenda Council on Employment, 2014

Committee on Employment and Social Affairs, 2014
} 
phenomenon developed throughout citizen's lifetime. Since a great deal of non-formal institutions are in charge of providing occupational and professional training in Spain, our proposal is based on the importance of recognizing these professional competences in the field of Languages for Occupational Purposes (EOP), and their contribution to the social change initiated in a wide range of professions.

Our study is the result of a research project supported and funded by the Regional Government of Extremadura ${ }^{4}$, developed through the research consortium between GExCALL ${ }^{5}$ research group and the multimedia software company FMI (Interactive Multimedia Training). The result from this partnership was the design and transferability of multimedia/online EOP courses, an innovative proposal aimed at achieving recognition in English for occupational purposes in the fields of tourism and commerce, two of the most expanding economic sectors in this region (Extremadura), Spain and in a great deal of other countries.

Through the survey of the current linguistic needs in the aforementioned professional fields and the contextualization of the whole project, the study reported in this article analyzes the transference rate of the EOP multimedia/online courses, and gains insight into the factors which may have fulfilled users' expectations and those which may have caused the initiative to fail. Implications from the lack of consensus in establishing official certification forprofessional achievements will be discussed towards the end of the article.

\section{EOP AND LANGUAGE COMPETENCE AT THE WORKPLACE}

\section{A. Contextualization}

Dudley-Evans \& St. John (1998) describe the coexistence of two main branches within ESP: English for Academic Purposes (EAP) and English for Occupational Purposes (EOP). The first one has to do with technical and specialized subjects taught during academic careers, whereas the second deals with courses specifically designed to help professionals evolve in their work and to facilitate learning of linguistic skills connected with their job needs. Alcaraz (2000), on the other hand, based on these categories and on Widdowson's belief (Widdowson, 1983) that all linguistic uses are specific, coins the acronym IPA (Inglés Profesional y Académico - Professional and Academic English), which includes, beyond English for Academic and Professional Purposes, the language used in scientific research and technological development, EST (English for Science and Technology). Though it is not easy to categorize ESP branches, authors seem to agree that each profession demands knowledge on concrete aspects and specific language according to the area of job expertise (Bhatia, 2016).

The need for acquiring linguistic competences in professional settings has been discussed in studies devoted to teaching languages for occupational purposes. Kankaanranta \& Louhiala-Salminen(2010), Evans (2010) and Hellekjær \& Fairway (2015) analyzed the use of English in international business interactions and came to the conclusion that many of the users used the lingua franca more than their mother tongue, and that knowing the other part's context (cultural and corporate) would help communication succeed. Cutting (2012) notes that in spite of the lack of English language proficiency requirements for airport staff, there exists a growing interest in making these professionals cope with ordinary and uncommon situations that require, most of the time, the acquisition of specific terms and the development of communicative strategies. Peters \& Fernández (2013) state that workers have specific and particular lexical and linguistic needs in their daily work contexts, and that these demands can be successfully accomplished under appropriate training conditions (Smart \& Brown, 2002). Lam, Cheng \& Kong (2014) find that nowadays workplaces have turned mobile, demanding better communication and interaction skills from users. According to these authors, communicative inefficacy can also lead to productivity loss. In this context, and considering the need for effective proposals covering the wide area of English for Occupational Purposes, it is also important that EOP learning programs are officially recognized, which proves difficult since how or what the requisites are still remain in question for educational institutions and users (Tajuddin, 2015).

National reports on linguistic demands for each job family, covered in the following section, have come from the European level. These were the identification of professional requisites from the Lisbon (Council of Lisbon, 2000) and Barcelona (Barcelona European Council, 2002) Councils, and the establishment of the Competence and Qualifications Framework, regulations which gave rise to a growing discussion about educational and occupational learning needs. Furthermore, finding solutions to improve young adults' and unemployed workers' ability to be hired has been set as a priority in most government employability agendas. This job search demands knowledge, skill updating and official recognition for skills and it is on this last need that our proposal is based. The complexity and constraints of language learning policies (Weinstock, 2014) covers a great deal of fields, including status, corpus, acquisition, and recognition, among others. The lack of qualifications, especially felt in some technical jobs and those related to language demands, has its origin in factors such as population aging, language barriers, the shortage of ICT expertise and a straightforward policy on professional competence certification. Once formative deficiencies have been identified and partially

\footnotetext{
${ }^{4}$ Project data: Creación de cursos on-line/multimedia de idiomas con fines ocupacionales para la certificación profesional y homologación Europea.(Reference: PDT06A047). Development, innovation and technological transference projects resulting from the cooperation between regional research groups and Extremaduran enterprises (DOE n. 44, April 15, 2006)

5Grupo Extremeño de Enseñanza de IdiomasAsistida por Ordenador [Computer-Assisted Language Learning Extremenian Group]
} 
overcome, the need for official recognition of such competences in professional contexts emerge. Official certification is urgently needed in occupational and vocational education in order to transfer professional skills and aptitudes when applying for jobs demanding such skills. Thus, to promote mobility, a European VET area was proposed with the objective of certifying competences all over Europe(Vocational Education and Training, 2006 p. 4).The OECD (Organization for Economic Co-operation and Development, 2007) described a set of features that should be kept in mind when trying to create an efficient qualification and certification system: increase flexibility and responsiveness; motivate young people to learn; link education and work; facilitate open access to qualifications; diversify assessment processes; make qualifications progressive; make them more transparent; facilitate review of funding and increase efficiency, and; lead to improvements in the way the system is managed (Qualifications Systems, 2007, p 12-13).

Based on these characteristics, the creation of NQFs (National Qualification Frameworks)helped to establish qualifications levels, and may be said to function as an intermediary between recognizing students' and workers' competences and their homologation by a more general body, the European Qualification Framework (EQF). In this context, the need to certify knowledge in foreign languages was regulated by the Council of Europe under the development of the Common European Framework of Reference (CEFR), published by Cambridge University Press in 2001. The CEFR arose from the necessity of establishing a coherent evaluation and certification system that measured the acquisition of language skills and minimized the diversity of results used all over Europe (North, 2007).

Nowadays most official general language courses are based on these certification criteria (A1-C2 levels).Despite this fact, it is not easy to get recognition based on national CEFR standards when going abroad. The problem is due to the general framework conveyed by the CEFR, in which level descriptors and competences can be interpreted with a certain degree of flexibility. Hopefully in a near future a more fixed certification will be achieved and minor differences across countries will be minimized. However, the lack of recognized certification in ESP (except for some specific areas such as Business English or English for Tourism) and in EOP remains unsolved, a situation which justifies our research.

\section{B. Competence Qualification and Professional Achievements in Spain}

The establishment of policies leading to official recognition of professional competences, as recommended by both European guidelines (seen in the previous section) and national regulations, sets the goal of our study. The foundation of our proposal is primarily based on the analysis of national documents showing the competences in demand within a great deal of professional fields in Spain: official reports describing the professional qualification included in the general framework of INCUAL (National Qualifications Institute, 2014) and the National Training Plan - Plan Nacional de Formación e Insercción Profesional (Plan FIP,1993-2007), and Professional Training Plan for Employment from 2008, documents which describe the level of language competence to achieve at work and identify formative deficiencies in professional families regarding foreign languages and other specific and cross-curricular professional competences, both in formal and non-formal education (2002). In this sense, how national language agencies and services influence language practices have proved to be effective (Edwards, 2011) though key areas on linguistic policies remain uncovered.

With this in mind, the linguistic requirements of all the jobs included in the professional families of tourism and commerce were analyzed, two leading sectors at a regional (Extremadura) and national (Spain) level with an increasing number of visitors.

According to the National Training Plan, Table 1 shows the linguistic needs in commerce-related professions (shop assistant, sales management, cashier, shop manager and sales agent). The columns in blue describe the linguistic levels demanded by each profession.

TABLE 1

LINGUISTIC NEEDS IN THE COMMERCE PROFESSIONAL FAMILY (2002:184)

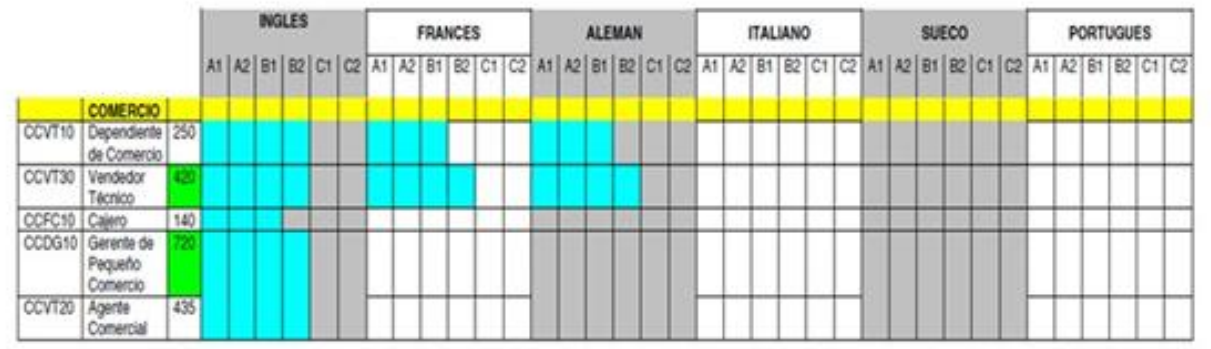

As seen in Table 1, a B2 level of English is advised for all jobs related to commerce (except cashier, for which a B1level is recommended). This higher language level demand could be justified by the need these professionals have to continuously interact with clients. On the other hand, we can see that only shop assistant and technical sales agent present linguistic demands in other languages different from English(German and French), indicating that English dominates communicative interactions between workers and clients.

To establish the linguistic needs in this sector, we also needed to know which language competences should be 
included in the design of occupational courses intended for these professionals. Thus, professional qualifications in the field of commerce and marketing were analyzed from the specifications ruled by the National Qualification Institute (INCUAL, Royal Decree, 1999).

Professional qualifications for sales activities comprise four general units with competences related to interaction with clients in different types of commercial facilities, on their own, or in small/medium enterprises. From all the relevant jobs in commerce, we chose for our proposal shop assistant, a profession for which the occupational module Professional English for Commercial Activities is proposed in INCUAL. In terms of productive sectors, these professionals will presumably work at firms or associations, in the public or private domain, dealing with the public in sales and post-sales situations. Consequently, a module called Professional English for Commercial Activities is also recommended by the National Qualifications Institute.

On the other hand, the tourism industry is directly linked to economic cycles, being affected by crisis, and flourishing in times of economic prosperity. In most tourism-related jobs, mobility is evidenced in the existence of an increasing number of foreign employees in restaurants and bars, as well as Spanish professionals in other European countries. Knowing foreign languages is consequently needed in order to advance in their jobs. As a matter of fact, tourism sector professions demand mastering English (oral and written) to effectively interact with the public, and may need other foreign languages as well. Thus, and based on the National Training Plan, waiters/waitresses (table2), cover 54\% of job vacancies and English is the language these professionals should know by achieving, at least, an A2 level of linguistic proficiency (Plan FIP, 2002:149). So, by analyzing Table 2, we can see that in waiter-related positions, an A2 level has the purpose of facilitating communication and interaction with clients, also being necessary the knowledge of other foreign languages.

TABLE 2

LINGUISTIC NEEDS IN THE TOURISM PROFESSIONAL FAMILY (2002:189)

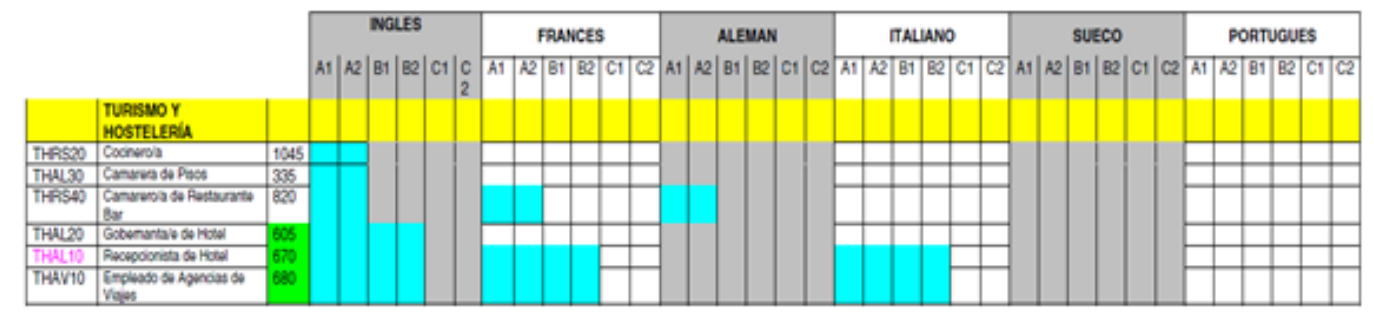

English is also a demand in tourism based on INCUAL specifications. After analyzing two professional qualifications(restaurant and bar service), we see that one of the competence units is communicating in English as an independent user, in restaurant service, and one of the formative modules is Professional English for Restaurant Service. We confirm that teaching specific English, based on practical and real contexts and situations is gaining more importance nowadays.

\section{Project Overview: Creation of Online/Multimedia Language Courses for Professional Qualifications and Official Recognition}

Our research, developed under the auspices of a research project on teaching innovation and technological transfer to productive and educational sectors, is based on the creation of language courses for occupational purposes online (Moodle) and with multimedia support, following the aforementioned European/national guidelines. According to the general scope of the project, the EOP courses were designed in four languages (English, French, Portuguese and Italian), covering two occupational areas (commerce and tourism), due to the interest for Spain and Extremadura -the Autonomous Region where the research is conducted and funded.

Despite the levels advised by the analyzed documents, we decided to base our proposal on levels A1/A2 (according to the CEFRL), because of the low language level these professionals had in most skills and because it is a level common to both professions (shop assistants and waiters) under study, but always bearing in mind to return to language training at higher levels (B1/B2) in a near future. A context study also revealed that these professionals need foreign language education through the use of technology, where students are responsible for their time and learning process and without geographical, labor or personal barriers. Our teaching perspective is based on tasks, meaningful activities which challenge learners to interact in the target language without the need of traditional presentation of linguistic items preceding the interaction (Partridge \& Starfield, 2013). The design of these target tasks, job-specific needs that aim at meeting participants' professional goals, is based on situations that learners have to cope with outside the classroom or the platform, in our case, welcoming customers, taking orders, serving food and beverages, selling products, handling payments or giving advice to potential customers, among others. Authentic material (menu types, ingredients, list of drinks, invoices, bills, shopping centers, department stores, etc.) is a key element to develop appropriate teaching proposals and an essential factor for EOP learner empowerment.

What is more, the guided content structure of the multimedia version makes this option seem appropriate to users with less digital competency, those who need more consistent support from the teacher. On the other hand, the online 
version through the Moodle platform aligns with the current educational paradigms using technologies, since content management platforms allow students to be more active, autonomous and responsible for their own learning, to organize their time and eliminate geographical, physical, economical and personal barriers to access content. The online version, mainly designed for students to work autonomously (although students can communicate with tutors synchronously whenever they like), constitutes an up-to-date distance educational proposal in English for Specific/Occupational Purposes. Its future potential is limitless.

\section{ThE PRESENT STUDY}

The main scope of our proposal covers the results obtained after gathering information on course dissemination, assessment and exploitation by final users. Gaining insights into the transference rate of the EOP courses, analyzing the profile and degree of acceptation by the target groups and obtaining preliminary data on possible linguistic certification obtained by users are key factors to assess the efficiency of our teaching initiative. However, and as it will be shown throughout the development of our study, completing a course and obtaining a passing attendance certificate do not necessarily involve getting linguistic certification according to the CEFRL.

\section{A. Research Questions}

The research questions raised to study dissemination and assessment of the EOP courses by non-formal educational entities are as follows:

(1) To analyze EOP course transference rate (\% of institutions and students using the courses) and factors making the multimedia/online courses a successful proposal;

(2) To gain insights into the learning expectations outcomes and failures.

Addressing the research questions above, and combining qualitative and quantitative analysis, the present study aims to cover an important gap in the field of English for occupational purposes by analyzing the opinion of the labor force about the parameters which could make EOP language courses become a successful bet, and how official certification and level recognition could improve their chances to incorporate or be promoted in professional contexts.

\section{B. Population under Study}

The participants in this study were adults taking continuing education courses in non-formal teaching institutions around Spain. Some of the courses were sponsored by public institutions in Spain such as the National Service for Employment (SNE-Servicio Nacional de Empleo), while others were offered by private initiatives. The distribution of the courses and participants through twelve small and medium-sized national enterprises delivering the courses is as follows:

A1 y A2 English courses for waiters and bartenders. The total number of students enrolled in the A1 level course is 164: five institutions with a number of enrolments between 5-15; five between $16-30$, and two between 31-50 students. The number of candidates enrolled in the A2 waiter and bartender courses shows greater participation, which may be caused by the increasing demand of English competence in this sector. The 257 students enrolled are distributed as follows: five institutions have between 5-15 students; four between16-30; two ranging from 31 and 50, and one company between 51-70 participants.

A1 y A2 English courses for shop assistants. The number of participants in the shop assistant course is lower in both levels: 135 students in the case of A1: seven institutions with a number of enrollments ranging from 5-15; three between 16-30, and two between 31-50. As for the 195 students enrolled in the A2 shop assistant course, we find the following distribution: seven institutions with a number of participants between 5-15 and five ranging between 16-30 students.

To complete the database of participants, the company managers were firstly contacted by telephone, informed about the study scope and asked to provide researchers with the affiliation of the students who had taken the courses. The whole sample of students was emailed describing the survey and offering the possibility to be contacted by phone to hold in-depth interviews. From the database provided (751 candidates), only 411 (55\% percent) answered the email positively and filled in the questionnaire. Additionally, an average $9 \%$ agreed to have a phone interview if necessary. In the table below the final figures of participants are shown:

TABLE 3

NUMBER OF PARTICIPANTS

\begin{tabular}{|l|l|l|l|}
\hline & Total Sample & Research Sample & Interviewees \\
\hline A1 Waiter \&bartenders & 164 & $88(54 \%)$ & $8(10 \%)$ \\
\hline A2 Waiter \&bartenders & 257 & $147(57 \%)$ & $9(6 \%)$ \\
\hline A1 Shop assistant & 135 & $68(50 \%)$ & $6(9 \%)$ \\
\hline A2 Shop assistant & 195 & $108(55 \%)$ & $14(14 \%)$ \\
\hline Totals & 751 & $\mathbf{4 1 1}(\mathbf{5 5 \%})$ & $\mathbf{3 7}(\mathbf{9 \%})$ \\
\hline
\end{tabular}

\section{Participants' Demographic Data}


The percentage of men and women is quite homogeneous in both courses and levels: seven institutions present an approximate $50 \%$ of men and women enrolled; two of them present one third of men against 30\% of women, whereas the last two show a $40 \%$ of men against an approximate $60 \%$ of women. The distribution indicates that both professions do not show gender preferences and that both men and women are interested in and capable of developing a career in these sectors.

Where age is concerned, four institutions noted having students with ages ranging from 16-30 years old, five between 30-45, and three with ages between 45-60.A wide range of academic background and qualifications is seen regarding their academic levels. The institutions under study noted that most of their students held high school education and vocational training certificates, ordinary secondary school levels and a varied range of university degrees. With these figures, we can see that participants are interested in learning and being trained after finishing compulsory education. However, the difficulty of finding a job in the current economy leads citizens even with university degrees to look for vocational and occupational training apart from their academic expertise and qualification.

Another aspect worth mentioning is the role of professional training in young people's education, a population which, unsatisfied with compulsory syllabi, tries this formative modality to acquire technical and professional expertise which can help them enter the labor market directly.

\section{Survey Tools}

The instruments used in the study included: (1) a student opinion questionnaire designed with the purpose of gaining insight into the reasons for the successful transference rate of the courses and/or main failures, and;(2) a set of questions to analyze the connections between official recognition and certification of EOP competences and its influence on professional achievements.

The questionnaire, built with Survey Monkey, was designed by the authors with several areas key to student personal opinions and beliefs on the topics under study. It was first tested in a pilot group of 25 students and two company managers of the total population comprising the research. Test validity was obtained by requesting feedback and suggestions from two experts in the field of psychology and two additional specialists in ESP, both groups familiar with the constructs and the purpose of the research. Once the pilot phase had been finished, the questionnaire was tested for reliability using Cronbach's alpha to test internal consistency of items, for which the standard for test reliability begins at 0.6 . The calculation performed concluded with a 0.8 alpha. Given that this index ranges between 0 and 1 , which is above the standard 0.6 , the reliability of the questionnaire can be considered appropriate.

The opinion/belief questionnaire included items concerning: (1) the number of students enrolled in each course/level; (2) their academic level; (3) their current jobs and future perspectives; (4) the number of students who had completed the courses; (5)main strengths of the EOP courses; (6)reasons to leave the courses; (7) the kind of certification obtained on completion; (8) whether the courses helped participants improve their linguistic competence, and;(9) projection on their professional status/expectations.

Items were measured on a Likert scale, ranging from 1 to 5 points, with 1 being totally disagree and 5 totally agree, measuring the following items to cover our objectives: those referring to the success of the transference rate -research question 1: (1) course content and general motivation; (2) interactivity; (3) collaboration; (4) autonomous learning, and; (5) novelty of the course format (online/Multimedia); and the variables to measure expectations, failures and reasons to leave the courses - research question 2: (6) task difficulty (English level); (7) lack of digital competence; (8) lack of time competence to manage the course deadlines, and; (9) no connection with my current job or other reasons. See tables 4, 5, 6 and 7 in the result section.

Interviews were used to complement the survey data and give us deeper insight into the opinions, attitudes and beliefs of our target groups. In particular, interviewees were asked to discuss their views about the importance of their English competence being officially recognized in order to improve their work achievements.

\section{E. Test Administration and Procedure}

To achieve our goal, the first step was to contact the multimedia software company (FMI)with which our project was initially developed -FMI was the project partner in charge of dissemination, transfer and commercialization of the EOP courses-.After a preliminary analysis, we identified a reasonable number of non-formal educational institutions around Spain to which the EOP courses had been distributed. Next, we developed, tested and validated the 18-question online questionnaire to cover the objectives.

Although the main survey instrument used was the questionnaire designed to gather quantitative data about participants' opinions and to evaluate a set of factors related to the general objectives, partial interviews were used to complement the survey data and give us some deeper insight into the beliefs of our target group; in particular, interviewees who abandoned the course were asked to discuss the main reasons they did so. Thus, the perspectives shown in our findings represent the views of two groups of informants: (1) a large body of participants answering the questionnaire, and; (2) the feedback of 37 students interviewed by phone/Skype.

\section{RESULTS}

\section{A. Objective 1 - Transference Rate: Factors Making EOP Multimedia/Online Courses a Successful Proposal}


From the research sample (411 candidates who filled in the questionnaire), only $74 \%$ finished the courses successfully, a total of 310 students distributed as follows: $81 \%$ in the case of waiters (190candidates) and 68\% (120participants) in the case of shop assistants. An overview of the total sample is shown in Table 4.

TABLE 4

NUMBER OF STUDENTS FINISHING THE COURSES

\begin{tabular}{|l|l|l|l|l|}
\hline & $\begin{array}{l}\text { Total Research } \\
\text { Sample }\end{array}$ & $\begin{array}{l}\text { Participants Finishing } \\
\text { the course \& } \\
\text { completing the survey }\end{array}$ & Interviewees & $\begin{array}{l}\text { Participants } \\
\text { leaving the } \\
\text { course }\end{array}$ \\
\hline Waiter \&bartender (A1 \& A2) & $\mathbf{2 3 5}$ & $\mathbf{1 9 0}(\mathbf{8 1 \%})$ & $15(8 \%)$ & $36(19 \%)$ \\
\hline Shop assistant (A1 \& A2) & $\mathbf{1 7 6}$ & $\mathbf{1 2 0}(\mathbf{6 8 \%})$ & $12(10 \%)$ & $38(32 \%)$ \\
\hline Totals & $\mathbf{4 1 1}$ & $\mathbf{3 1 0}(\mathbf{7 4 \%})$ & $\mathbf{2 7}(\mathbf{9 \%})$ & $74(26 \%)$ \\
\hline
\end{tabular}

In general terms, all institutions and participants have a positive opinion about the course content and the design structure, which justifies the reasonable high percentage of students who finished the courses, $74 \%$ as a whole.

Focusing our attention on students' opinion on the main features which made the courses an appealing teaching/learning proposal (variables 1-5), Table 5 summarizes the mean values over a five point Likert scale.

TABLE 5

MEAN VALUES OF MAIN VARIABLES

\begin{tabular}{|l|l|}
\hline Transference rate: course variables & Mean \\
\hline 1. Content and motivation & 4.0750 \\
\hline 2. Task interactivity & 3.5719 \\
\hline 3. Collaboration & 3.3667 \\
\hline 4. Autonomous learning & 4.0625 \\
\hline 5. Novelty of the course format (online / Multimedia) & 4.3625 \\
\hline
\end{tabular}

From the results, the novelty of the course format (online/multimedia), which enabled them to coordinate work and study without time and place restrictions, shows the highest percentage, 4.3 over a 5-point scale. The course specific content and the possibility to work autonomously present positive results as well (above 4 points). The implicit interactivity and opportunities for collaboration show an average feedback of 3.5 points as shown in Table 6 .

To analyze whether these independent variables influence students' perception on the course transference rate, and consequently the success of the proposal $(\mathrm{p}<0.005)$, we used a multiple regression analysis, estimating a model whose results are presented in Table 4 . In this model, some of the items were found significantly related.

TABLE 6

RESULTS OF REGRESSION ANALYSIS

\begin{tabular}{|l|l|}
\hline Variables & \\
\hline Independent Variables & \\
\hline 1. Content and motivation & 0.589 \\
\hline 2. Taskinteractivity & 0.558 \\
\hline 3. Collaboration & 0.645 \\
\hline 4. Autonomouslearning & 0.811 \\
\hline 5. Novelty of the course format (online / multimedia) & \\
\hline Dependent variable & \\
\hline Factors affecting the transference rate / success of the proposal & 0.675 \\
\hline $\mathrm{R}^{2}$ & \\
\hline$* \mathrm{p}<.05 ; * * \mathrm{p}<.01 ; * * * \mathrm{p}<.001$ & \\
\hline
\end{tabular}

In terms of getting insight into what extent the independent variables (1-5) affect the success of the transference rate of the EOP courses, we find that the "Novelty of the course format (online/multimedia)" and students' perception about the implicit potential to work at their own pace ("Autonomous learning") would be positively associated (0.811 and 0.645 , respectively).

Secondly, it was empirically confirmed that "task interactivity" and students' perceptions regarding the "possibility of collaboration' with the instructors and other users are also associated ( 0.589 and 0.558 respectively).

\section{B. Objective 2 - Gaining Insights into Learning Expectations and Failures.}

Among the reasons why participants failed to complete the courses successfully (variables 6-10), the difficulty to finish the tasks on time (lack of time management competences) reveals the most relevant factor. Showing lower percentages, a couple of variables are found below 0, 3 points from the global 5-point scale: 'the difficulty of the tasks' and 'the lack of digital competence'. The lack of connection with their current positions or interest is placed in the last position of the scale, around 1 point. Finally, under the label 'others' a heterogonous group of factors such as 'finding a new job', 'technological media available' and 'lack of official recognition of the courses' (usefulness) reveals significant factors for leaving the courses unfinished. Results are shown in Table 7. 
TABLE 7

REASONS TO LEAVE THE COURSES

\begin{tabular}{|c|c|}
\hline Reasons to leave & \\
\hline 1. Task difficulty (English level) & 2.976 \\
\hline 2. Lack of digital competence & 2.432 \\
\hline 3. Lack of time competence to manage course deadlines & 4.345 \\
\hline 4. No connection with my current job / Interest & 1.065 \\
\hline 5. Other & $3.567 *$ Discussed in the interviews \\
\hline
\end{tabular}

To analyze whether the variables included in the category "others" influence students' decision to leave the course unfinished $(\mathrm{p}<0.005)$, we used a multiple regression analysis to test the four main variables $(10.1-10.4)$, estimating a model whose results are presented in Table 8 . In this model, some of the items were found to be significantly related.

TABLE 8

RESULTS OF LINEAR REGRESSION ANALYSIS

\begin{tabular}{|l|l|}
\hline Variables & \\
\hline Independent Variables & \\
\hline Other reasons to leave the course & 0.510 \\
\hline 10.1. Getting a new job & 0.478 \\
\hline 10.2. Lack of digital media & 0.321 \\
\hline 10.3. Not covering learning expectations & 0.823 \\
\hline 10.4. Course recognition (usefulness) and work achievements & \\
\hline Dependent variable & \\
\hline Leavingthecourseunfinished & .530 \\
\hline $\mathrm{R}^{2}$ & \\
\hline$* \mathrm{p}<.05 ; * * \mathrm{p}<.01 ; * * * \mathrm{p}<.001$ & \\
\hline
\end{tabular}

In detail, analysing the hypothesis about which of the 'other' variables could influence the decision to leave the courses, 'the lack of course recognition (usefulness)', getting by far the highest results, would be positively associated $(b=0.823)$. All the other factors but getting a new job, with 0.510 , are not directly associated with the decision to leave the courses unfinished ('lack of digital media available' and 'learning expectations', with 0.478 and 0.321 respectively).

In this sense, when analyzing the variable, 'lack of official certification' in the interviews, we see that most of the participants noted the requisites to pass the course (completing the course successfully and taking a final test to get the course certificate), did not result in achieving an official recognition according to the CEFRL. They claimed that in spite of getting a completion/attendance diploma, official recognition of proficiency level was not guaranteed, and in the case they needed to certify their language level (A2, B1) for professional purposes, they would have to take official exams run by external entities based on general English standards and not for specific /occupational purposes.

\section{Expanding Reasoning through Phone Interviews}

To gain insight into the perception students had between getting official recognition and improving work achievements, phone interviews were held with 27 participants $(9 \%)$ of the total sample. To the question on whether students got official recognition after the course completion or not, four students admitted they did not know the existence of such a possibility while twenty-three noted the difficulty/impossibility of obtaining a foreign language official certificate following the EOP course instruction.

In this sense, for the question whether it would be professionally rewarding to have a standardized EOP certification tool, twenty-two of the interviewees answered positively, whereas one of the candidates answered that he did not know how it could affect his professional promotion. The results support the importance of giving an urgent solution to the linguistic certification gap in English for specific and professional purposes.

As for the usefulness of the courses in their job performance, promotion and professional achievements, only two participants stated that the diploma had helped them progress at work, while the remaining 25 answered negatively. The dearth of a relationship between foreign language learning and job achievement informs us on the still scarce control of success (or lack of) of this kind of specialized language courses. Nowadays, with the difficulty people have in finding a job and improving professional competences, official recognition may be decisive for this process, as well as promote advancement in an increasingly global labor market. Despite this pitfall, twenty-six interviewees answered positively that they might progress in their jobs if this specialized training was officially recognized according to European standards (e.g. B1 in English for shop assistant, A2 for English for Restaurant Services and the like).

Finally, in the last part of the interviews, participants were asked about how the achievement of official recognition could influence variables such as 'getting a new job in/outside the sectors under study', 'promotion in their current positions' and 'gaining cultural awareness and self-satisfaction'. Results are shown in Table 9. 
TABLE 9

DESCRIPTIVE STATISTICS - WORK ACHIEVEMENTS WITH/WITHOUT CERTIFICATION

\begin{tabular}{|l|l|l|l|}
\hline \multicolumn{2}{|c|}{$\begin{array}{l}\text { Getting a new job } \\
\text { in the tourism /commerce industry }\end{array}$} & CATEGORY & Mean \\
\hline Promotion in their current jobs & without certification & 27 & 2.0792 \\
\cline { 2 - 4 } & With certification & 27 & 3.8417 \\
\hline Getting a job in a new field & without certification & 27 & 3.0542 \\
\cline { 2 - 4 } & With certification & 27 & 4.7530 \\
\hline Self -satisfaction and cultural awareness & without certification & 27 & 2.7719 \\
\cline { 2 - 4 } & With certification & 27 & 3.2698 \\
\hline
\end{tabular}

According to the contrast of means, there are differences between holding/not holding an official certification in English for occupational purposes, the biggest differences being observed in the variables 'getting a new job in the tourism/commerce industry' and 'promotion in their current jobs', indicators in which participants got an average score that exceeds 1.7 points over the average score. As for the variable 'self-satisfaction and cultural awareness', our statistical analysis also shows differences as higher than 1 point, while the lowest value between the mean scores is obtained in the dimensions 'getting a job in a new field'.

\section{CONCLUSIONS}

Europe is striving towards building a union of equality in all aspects of its existence. A crucial focus towards reaching this goal lies in matters concerning education. The cultural perspective of mutual understanding makes communicating through language one of the most obvious ingredients in the recipe for success. This paper has addressed the question of formative needs in foreign language competency for selected working collectives in equivalent professions across Europe.

The need for professional expertise increases in economic crisis periods and the difficulty in finding a job makes people apply for initiatives to learn (or update) skills in order to access the labor market or to keep their current jobs. As seen, these citizens are not only youths who finish university and are not able to find a job, but also those who leave school and need to open horizons far from their initial expectations. Whatever the circumstances, the demand for professional courses is a fact, especially when they combine linguistic acquisition and development of professional competences. From the results, it can be concluded that the courses grasp the interest of users who want to find a job, advance in their current positions and even want to pursue personal or professional development, such as going abroad. In an ever-global world, mastering foreign languages is an urgent need, and if that education comes with the practical learning of technical skills, the added value is priceless. The results are aligned with the goals promoted by the European Union when defending educational and mobility policies - to enhance the development of versatile citizens, prepared to embrace the demands of a constantly-changing society, processes in which foreign language certification is a priority. However, the lack of official recognition of the linguistic level demanded in professional fields of the labor market still remains unsolved.

Another important conclusion is that vocational training with technological support is seen as a challenge, a teaching proposal which allows users to acquire and develop competences (linguistic, in our case) not being subject to geographical or time restrictions, allowing them to be autonomous and responsible for their learning.

Yet we still have much to achieve. In our educational system, vocational instruction is often seen as the last option for students who abandon secondary education without knowing what lies ahead in terms of future job interest. We are convinced that proposals like ours could make vocational education, both in formal and informal settings, acquire the status it deserves. Getting official certification is an objective that requires effort from public administrations, educational policies, teachers and students. Few entities offer vocational courses, and recognition usually becomes a slow and painful process, sunk in bureaucracy and with no guarantee of success. Many things have to change to enable occupational-oriented teaching to be valued and recognized by regional, national and European institutions and included in their catalogues of official training.

Nowadays, along with the theoretical bases needed to develop any given job, professional competences have a decisive role for accessing the labor market - to know and know how to do something-a dimension which is present in vocational courses. The world economic crisis and the global changes suffered all over the world have created the need for being technically efficient when looking for a job. What is less valued today can be dominant in the near future. Social and work demands point in that direction.

\section{FUtURE ACTION LINES}

No field of human activity achieves an unchanging proficiency and the proof is the knowledge paradigms which, despite surviving for some time, become insufficient and are replaced by others, more demanding and up-to-date. Like those paradigms, this proposal also presents limitations and demands of future action lines. 
The first one has to do with course format. The mobile version of the courses in a mobile application, allowing anywhere/anytime possibilities for learning, is making progress, an app in which we have been working for several months to create both community generated content, as well as a community of new learners.

Another direction for future research lies in the creation of specific corpora for the professions considered by our proposal. We should proceed to a lexical compilation on different professions in the field under study to facilitate occupational language teachers' work when designing specific courses. It's a need considering that education is more and more based on a pragmatic aspect and the student, and his/her work and personal needs, are placed in the center of the process.

Finally, and from the results examined here, we all know that students' needs are based, in most cases, on obtaining a diploma which recognizes the effort expended and the learning outcomes achieved. However, as we have seen through the questionnaires and interviews undertaken, certification is issued but official recognition is not always achieved. We believe it is urgent to create a certifying entity with objectives, criteria and requisites so that institutions can offer this quality guarantee and students can access the recognition of their knowledge and abilities.

\section{REFERENCES}

[1] Alcaraz Varó, E. (2000). El inglés profesional y académico. Col. El Libro Universitario. Serie Filologíay Lingüística). Madrid: Alianza. 240 pp.

[2] Barcelona European Council. (2000). Presidency Conclusions. SN 100/1/02 REV1.

[3] Bhatia, V. K. (2016). Critical genre analysis: Investigating interdiscursive performance in professional practice. London: Routledge.

[4] Castiglione, D., \& Longman, C. (Eds.). (2008). The language question in Europe and diverse societies: Political, Legal and social perspectives. Oxford: Hart Publishing

[5] Commission of the European Communities. (2002). Proposal for a Decision of The European Parliament and of the Council adopting a multi-annual programme (2004-2006) for the effective integration of Information and Communication Technologies (ICT) in education and training systems in Europe (eLearning Programme), Brussels.

[6] Commission of the European Communities. (2003). Communication from the Commission to the Council, the European Parliament, the Economic and Social Committee and the Committee of the Regions - Promoting Language Learning and Linguistic Diversity: An Action Plan 2004 - 2006. Brussels.

[7] Commission Staff Working Document. (2008). The use of ICT to support innovation and lifelong learning for all - A report on progress. Brussels.

[8] Communication from the Commission to the Council, the European Parliament, the European Economic and Social Committee and the Committee of the Regions. (2007). E-skills for the 21st century: fostering competitiveness, growth and jobs. Brussels.

[9] Conference Conclusions: Building a European VET area (2007) Council of Europe (2001). Common European Framework of Reference for Languages: learning, teaching, assessment. Cambridge, Cambridge University Press.

[10] Council of Lisbon (2000). Presidency Conclusions. Retrieved May, 10, 2015, fromhttp://www.europarl.europa.eu/summits/lis1_en.htm.

[11] Cutting, J. (2012). English for airport ground staff. English for Specific Purposes 31, 3, 13.

[12] Dudley-Evans, A. \& St John, A. M. (1998). Developments in English for Specific Purposes: A multi-disciplinary approach. Cambridge University Press. Cambridge.

[13] Edwards, J. (2011). Language management agencies. In B. Spolsky (Ed.), Handbook of Language policy. Cambridge, UK: Cambridge University Press.

[14] European Commission. (1999). eEurope: An information society for all. Communication on a Commission initiative for the Special European Council of Lisbon. Brussels: European Commission. Retrieved May, 14, 2015, from http://aei.pitt.edu/3532/01/000681_1.pdf.

[15] Europass Language Passport. Retrieved April, 10, 2015, fromhttps://europass.cedefop.europa.eu/europasssupportcentre/language-passport.

[16] Evans, S. (2010). Business as usual: The use of English in the professional world in Hong Kong. English forSpecificPurposes 29, 153-167.

[17] Formación en Idiomas. Estudio de Necesidades de Formación en Idiomas Comunitarios en el Marco del Plan F.I.P. (2002). Needs Analysis in language training based on Plan FIP's Framework. Ministerio de Trabajo y Asuntos Sociales. Instituto Nacional de Empleo.

[18] Global Agenda Council on Employment. (2014). Matching Skills and Labor Market Needs. Building Social Partnerships for Better Skills and Better Jobs. Davos-Klosters, Switzerland. 22-25 January. () World Economic Forum.

[19] Hellekjær, G. O. \& Fairway, T. (2015). The Mismatch between the Unmet Need for and Supply of Occupational English Skills: an Investigation of Higher Educated Government Staff in Norway. The International Journal of Higher EducationResearch, 60 (4). Retrieved from: http://link.springer.com/article/10.1007\%2Fs10734-015-9882-x\#page-1.

[20] Information and Communication Technologies in Distance Education. (2002). UNESCO. Institute for Information Technologies in Education. ICT skills certification in Europe (2006). CEDEFOP Dossier series; 13 Luxembourg: Office for Official Publications of the European Communities.

[21] Instituto Nacional de Cualificaciones - INCUAL [National Qualifications Institute]. Real Decreto 375/1999, de 5 de marzo. (BOE del 16 de marzo de 1999).Retrieved May, 14, 2015, from http://www.boe.es/diario_boe/txt.php?id=BOE-A-2002-24348.

[22] Jordan, R. (1997). English for academic purposes: A guide and research book for teachers. Cambridge: Cambridge University Press.

[23] Kankaanranta, A.\&Louhiala-Salminen, L. (2010). "English? - Oh, it's just work!” A study of BELF users' perceptions. English for Specific Purposes, 29, 204-209. 
[24] Lam, P., Cheng, W. \& Kong, K. (2014). Learning English through workplace Communication: An evaluation of existing resources in Hong Kong. English for Specific Purposes 34, 68-78.

[25] North, B. (2007). The CEFR illustrative descriptor scales. The Modern Language Journal 91/4: 656 - 659.

[26] OECD (2007). Qualifications Systems: Bridges to Lifelong Learning. Retrieved May, 14, 2015, fromhttp://www.oecd.org/education/innovation-education/qualificationssystemsbridgestolifelonglearning.htm\#HTO.

[27] Partridge, B. and S. Starfield (Eds.). (2013).The Handbook of English for Specific Purposes. West Sussex: Wiley-Blackwell.

[28] Patten, A. (2001). Political Theory and Language Policy. Political Theory 29(5): 691-715.

[29] Peters, P \&Fernández, T (2013). The lexical needs of ESP students in a professional field. English for Specific Purposes 32, 236-247.

[30] EUR-Lex (2002). Proposal for a Decision of the European Parliament and of the Council adopting a multiannual programme (2004-2006) for the effective integration of Information and Communication Technologies (ICT) in education and training systems in Europe (eLearning Programme. Brussels. Retrieved May, 14, 2015, fromhttps://eur-lex.europa.eu/legalcontent/EN/TXT/?uri=CELEX:52003AE0404.

[31] Report on creating a competitive EU labor market for the 21st century: matching skills and qualifications with demand and job opportunities, as a way to recover from the crisis. (2014). Committee on Employment and Social Affairs. Report to the European Commission on new modes of learning and teaching in higher education. (2014). Luxembourg: Publications Office of the European Union.

[32] Smart, G., \& Brown, N. (2002). Learning transfer or transforming learning?: Student interns reinventing expert writing practices in the workplace. Technostyle, 18, 117-141.

[33] Tajuddin, A. H. A., (2015). A Malaysian Professional Communication skills in English framework for English for Occupational Purposes courses, (Ph.D. Thesis), The University of Nottingham. Retrieved April, 10, 2016, from http://eprints.nottingham.ac.uk/28747/1/AJAT\%202015.pdf.

[34] UNESCO-UIS. (2009). Guide to Measuring Information and Communication Technologies (ICT) in Education. Technical Paper No. 2. Montreal.

[35] Vocational Education and Training (2006). Helsinki Communiqué on Enhanced European Cooperation in Vocational Education and Training. Retrieved May, 14, 2015, from http://www.cedefop.europa.eu/files/helsinkicom_en.pdf.

[36] Weinstock, D. (2014). The complex normative foundations of language policy. Language Policy, Volume 13, Issue 4, pp 317333.

[37] Widdowson, H. (1983). Learning Purpose and Language Use. Oxford: Oxford University Press.

[38] World Economic Forum. (2014). Matching Skills and Labor Market Needs Building Social Partnerships for Better Skills and Better Jobs, World Economic Forum Global Agenda Council on Employment, Davos- Klosters, Switzerland 22-25 January. Retrieved March 12, 2015 from: http://www3.weforum.org/docs/GAC/2014/WEF_GAC_Employment_MatchingSkillsL abourMarket_Report_2014.pdf.

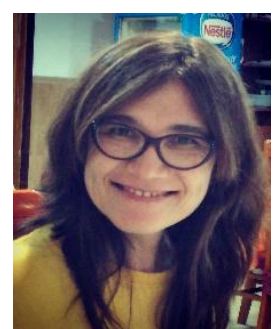

Mercedes Rico graduated from the Universities of Central Lancashire (BA) and University of Extremadura (BA, MA and PhD in English Philology). She is a Professor at the Department of English Philology at the University of Extremadura (Spain), institution where she has been teaching Information Technology applied to Language Learning and Communication Skills in Engineering for more than 25 years (undergraduated /postgraduate levels).

She has been the Director of the research Group GexCALL (http://gexcall.unex.es/en) since 2003, a group based on the unification of various scientific disciplines, forms an interdisciplinary core for study and research which include linguists, computer science experts, design professionals, and statistics experts, all working together on the integration of information technologies into the teaching of modern languages through the design of hypermedia systems, e-learning platforms, virtual environments, MALL and gamification.

Dr. Rico has supervised 10 Doctoral Theses and published over 50 indexed articles \& chapters. She has also coordinated and participated in more than 10 research funded projects (Regional, National and European) on language learning and linguistic analysis through ICT. She has authored or coauthored more than 60 presentations at national and international conferences.

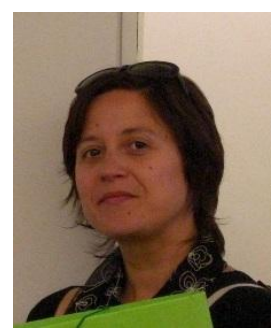

Paula Ferreira da Silva graduated in modern philology (Portuguese and English studies) in the University of Coimbra (Portugal). In 2016, she got a PhD in language for occupational purposes teaching and ICT in the University of Extremadura (Spain).

She has been a language teacher since 1996, teaching Portuguese and English in several institutions, both in Portugal and in Spain, namely high school, professional training and the university. Currently, she teaches Portuguese at Escuela Oficial de Idiomas, in Spain.

Dr. Ferreira da Silva is member of a research group and her main interests are e-learning, CALL and virtual worlds for language learning and cultural awareness. Her publications can be accessed in http://unex.academia.edu/PaulaFerreiraSilva 


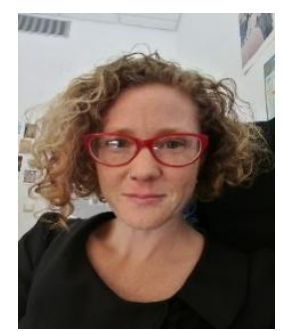

Laura Fielden graduated from the Universities of Extremadura $(\mathrm{PhD})$, University of North Carolina- Chapel Hill (Masters) and Appalachian State University (BA). She currently teaches at the University of Extremadura in the Department of English Philology, focusing in particular on instructing future and present language teachers in the Education Department, but also working with ESP for medical, tourism, and physical therapy students, among others. She has taught English and Spanish in Spain, Mexico and the United States at the tertiary level.

She is particularly interested in cultural factors and motivational issues and how these affect students in different fields, as well as how language through technology might help. She is a member of the research group GexCALL.

Dr. Fielden has coordinated or worked in a variety of programs in the past, including in study abroad in Spain, Cuba, and Mexico. 